\title{
OLDER ADULT EDUCATION IN TWO UNIVERSITIES: A COMPARISON IN THE NEW ZEALAND AND SCOTTISH CONTEXTS
}

\author{
Brian Findsen and Rob Mark
}

\section{INTRODUCTION}

Older people form an increasing proportion of the population in both New Zealand and Scotland and it is becoming clear that they will play an ever increasingly important role in the future of both countries. Debates on how to develop policies which support a wide range of their needs include the domains of health, economic security, work and leisure. In the field of education, the debate is focussing on how to meet their current and emergent learning needs.

This article discusses the situation of older adult education in universities in two Commonwealth countries in which the authors work. It investigates the circumstances of older people in both nations, focussing on how lifelong learning policy and practice has been implemented. Given that the focus is directed towards education (as opposed to the more elastic term "learning”), the role of one university from each country is examined and emergent issues analysed. Issues from each university are identified and discussed though caution is needed in generalizing the comparison to other universities from each country. While most trends are familiar to other universities, each of the Universities - Waikato and Strathclyde - has its own distinctive history and cultural context.

Information gathered for this article has been acquired through extensive professional experience in adult/continuing education of the authors in both countries and internationally, visits to each other's country, and examination of pertinent education and social policy documentation together with literature pertaining to learning in later life.

\section{WHO ARE OLDER PEOPLE?}

Deciding who is or might be an older adult is problematic. A simple assertion based on chronological age is not sufficient (Phillipson, 1998). While physiological decline is often associated with getting older, it is linked to a clumsy deficit model of ageing. Critical educational gerontology rejects such functionalist notions of ageing and asserts a more nuanced, holistic understanding of the ageing process and emphasises the language of possibility (Findsen, 2005; Phillipson, 2000). Further, we need to acknowledge that within and across cultural groups ageing is likely to be differentially experienced. More often than 
not, legal definitions associated with the award of pensions may determine who is older; normative notions of "retirement age" also function to influence how older age might be approached. As baby-boomers enter the early stages of the third age (Laslett, 1989), the "old rules” of how one should live in later life are increasingly jettisoned.

New Zealand: while the majority of older adults are from a European background, the latest census reveals an increasingly diverse population. According to the 2013 Census, in terms of age structure, the overall pattern is towards an ageing population (in 2013, people aged over 65 years constituted 14.3\%; 12.1\% in 2001); in the Māori and Pacific peoples, a more youthful population is evident (Statistics New Zealand, 2013). Hence, although overall New Zealand might be described as having an ageing profile, ethnic populations have very different life trajectories and life-chances compared with the European norm (Davey, 2006).

A government pension is universally available at age 65, regardless of financial status or gender. Accordingly, the receipt of a government pension may act as a proxy for "older person”. However, in terms of socio-cultural dynamics, the prospects of a professionallyoriented European urban male at age 65 are very different from those of a Māori woman who lives in a rural area, more likely as part of an extended family.

Scotland: The indigenous population is largely Scots with people living longer providing new challenges. Thorpe (2011), writing for the British Geriatrics Society, notes that there are 5.2 million people in Scotland with just over a million aged 65 and over. The number of over 65s is set to increase $62 \%$ by 2031 and there will be a 38\% rise in people aged 85 by 2016 and a 144\% rise by 2031. By 2031 there will be more "very old people” with a proportionately smaller, younger, employed, tax-paying population. While some of these older people will want to go on working and will have needs for skills training, an increasing number will have needs for education which focuses on their new-found leisure time. With two in five people in Scotland living with a long-term condition, there will be an increasing need to focus on health education and social care needs, particularly for those over 80 years of age (British Geriatrics Society 2011, http://www.bgs-scotland.org.uk/index.php/about13/ageinghealthstats).

\section{THE BROADER SOCIO-CULTURAL-ECONOMIC CONTEXT}

By world standards, New Zealand and Scotland might be described as "small countries". In New Zealand's case, while it is the size of the UK overall, in comparison with its larger neighbour, Australia, it is not big; for Scotland, it too is subject to its identity as part of the UK, covering about one third of the total land mass of the UK but accounting for approximately $10 \%$ of the UK population. Both countries celebrate their distinctiveness as nations with a "can-do" attitude and considerable resilience. The populations are relatively small - New Zealand has 4.5 million; Scotland has around 5.2 million - and in each case 
urbanisation has been a significant feature in shaping the landscape and lives of the people. Much of the New Zealand population is concentrated in the northern part of the North Island (one third of the citizens live in Auckland); much of the Scottish population is centred in the belt connecting Glasgow to Edinburgh.

New Zealand: An important dynamic in New Zealand society has been colonization by the British, resulting in many social/educational institutions being derived from the "mother country" (Dakin, 1992). Counter-acting this influence is the establishment of New Zealand as a bi-cultural nation (and hence, the use of the phrase "Aotearoa New Zealand"). The Māori language (te reo) is an official language used alongside English though people of Māori extraction constitute around $15 \%$ of the population. The Treaty of Waitangi, signed between the British Crown and mainly northern iwi (tribes) in 1840, is a blueprint for collaboration across the two main cultural groups. In particular, principles of protection, partnership, and participation are embedded into social policy statements, including policy in the (adult) education system (Jesson, 2010). However, given fairly keen immigration in recent decades, the population of this country is increasingly diverse, suggesting that the concept of multiculturalism might be adopted by many citizens who do not see themselves as part of the Treaty arrangement. The 2013 census (some overlapping categories) reveals that Europeans are 74\%; Māori 14.9\%; Pacific Peoples 7.4\%; Asian 11.8\%; Middle Eastern, Latin American, African $1.2 \%$ and other at $1.7 \%$ (Statistics New Zealand, 2013).

Scotland: Scotland is a modern, open economy and is rich in economic potential and natural resources. It has a broad industrial base which includes traditional industries such as oil and gas to renewable energy and creative industries and against a relatively subdued global economic environment, is now recording strong economic growth. Its population continues to rise and reached its highest ever total in 2013. The size of its ethnic population has doubled since 2001 to $4 \%$ of the population with Asians being the largest group and accounting for $3 \%$ of the total population. The Scottish Government is devolved from Westminster in London. It has a range of responsibilities which include health, education, justice and the environment. Some powers are reserved for the UK government in areas such as immigration, foreign policy and defense.The Government's aim is to encourage participation in the diverse cultural life of the nation and the widening of access to sport. Arts and culture are seen as bringing real benefits for communities and individuals and engagement in sport is seen as making an important contribution to the health and well-being of individuals.

Successive governments in Scotland have recognised the demographic challenges facing the country, in particular, the challenge of Scotland's ageing population. The Labour-Liberal Democrat coalition produced a strategy on older people and the challenges of an ageing population entitled All Our Futures (Scottish Government, 2007a). This set out an impressive vision of equal citizenship for older people, recognising the contributions to society older people had made and could continue to make, and recognising the obligations on the rest to enable their 
continued participation in society. It included policy interventions which enable older people as far as possible to remain active in their homes and communities (http://www.gov.scot/Publications/2007/03/08143924/9).

\section{LIFELONG LEARNING: DISCOURSES AND PRACTICES}

In many societies the concept of lifelong learning has replaced the notion of adult education (Findsen \& Formosa, 2011). This is especially the case in governmental policy where nations have sought to assert the rights of individuals to continue their learning throughout life (including learning in later life) but have not usually ensured that individuals have access to education. It has been convenient for governments to support the rhetoric of lifelong learning but not provide the funding for lifelong education. In both New Zealand and Scotland, policy proclamations have been acknowledging that lifelong learning is necessary but have been less clear on whether older adults are part of this mandate.

In the international literature on lifelong learning, four main themes have been articulated irrespective of geographical location. Of course, the active support for each theme varies from place to place and quite often the themes collide when it comes to their implementation.

The economic imperative: By far the most powerful discourse in lifelong learning is that of enhancing the economic capacity of both individuals, groups and the nation so that a country can compete globally in the marketplace (Davey \& Cornwall, 2003; Rothwell et al., 2008). Accordingly, most governments provide resources for vocational skills enhancement, development of generic skills, training for work programmes (on the assumption that there is work after training) and general employability attributes. Enterprise and innovation are especially valued in this new knowledge economy. In both New Zealand and Scotland, policies emergent from the lifelong learning agenda are saturated with such rhetoric.

Personal development: This theme is longstanding and previously linked to the notion of a liberal (adult) education. In recent times, the theme has lost much of its "knowledge for its own sake" ethos and adopted a more utilitarian tinge. Given that personal responsibility is at the root of this approach, few governments feel it is their prerogative to fund such individual development.

The active citizen: In the rhetoric of most governments, the idea of an informed and critical citizen is part of what it means to be part of a democracy. Applying this discourse, citizens need to be able to make informed choices and exercise their rights to vote and express opinion. In less democratic societies, this concept is not celebrated nor espoused as a desirable goal for lifelong learning. In the New Zealand context, universities in their statutes are expected to "act as the critic and conscience of society" so there is a clear expectation that 
higher education has an explicit role in helping to democratize society. In the Scottish context, a landmark in the development of adult education was the publication of the Alexander report (Scottish Education Department, 1975) which argued for education as a lifelong process and learning as a basic characteristic of life. The report singled out various groups which include older people recommending that adult education should be incorporated into a community development approach. The effects of Alexander were far reaching, across the whole sector of adult education including adult education in universities (Mark, 2013). In 2004 the community education services in Scotland were replaced by Community Learning and Development (CLD). This signaled a change in philosophy as well as in name. Today there are few existing local authority CLD services. Most have been rebranded into other service areas. The ideas and values which were once promoted have been diminished considerably.

Social inclusion/exclusion: While the notion of equal educational opportunity has been upheld in Western countries as a powerful myth, it has become recognized by many nations that in practice this is hard to achieve, especially for some groups in society who have undergone discrimination in terms of access and participation in education. Accordingly, marginalized groups have been identified and special efforts made to address historical discrimination through programmes of social inclusion. In (adult) education such groups may include the poor, ethnic minorities (including indigenous people), some women, some older adults, many new immigrants, prisoners and disabled people. In the context of New Zealand, where the Tertiary Education Commission (TEC) has identified Māori, Pacific Peoples and youth (under 25) as "priority groups", there are active policies to provide additional resources to these sectors of society (TEC, 2010). In some respects, the need for social inclusion or social equity programmes is to mitigate the effects of an economic model which values entrepreneurship, individualism and competition.

Reflection on the themes: In describing the main themes from a discourse of lifelong learning, it is timely to ask whether and how older people fit into these categories. In the economic model, often older people are given brief mention as they have often been marginalized in a workforce. Persistent stereotypes of older people as being disengaged from paid work and taking the place of a younger worker are difficult to change (Beatty \& Visser, 2005). Increasingly, in Western societies, especially as retirement is no longer compulsory, people in their 60s and 70s continue to work in the same or other workplace (as in encore or extended careers), perhaps in part-time or seasonal work. Both governments and employers have been slow in recognizing "the new order" in which older people in paid work is more normative. In such a context, training and professional development need to be available to all workers, regardless of age (Lindberg \& Marshallsay, 2007).

The idea of continuing to learn for individual development remains strong, especially amid the middle-classes. In adult education in both countries, providers such as universities, polytechnics/colleges, community schools, community centres have provided sustained educational opportunities. Participation studies around the Western world, several initiated by the National Institute of Adult Continuing Education (NIACE), point to a familiar scene of 
women dominating participation in many leisure/recreational activities (McGivney, 2006). Even though the New Zealand Government recently cut funding to high schools for adult and community education (ACE) in 2010 by $80 \%$ and to universities for ACE provision entirely in 2011, there are still pockets of provision from other providers such as the Rural Education Activities Programmes (REAPs). The self-improvement motive continues to be strong though the internet, rather than programme provision, may now meet some of this need.

Older adults are a heterogeneous sub-population (Findsen, 2005). While many older people retain active participation in civil society, others, particularly those entering the fourth age, find it challenging to remain engaged as active citizens. This will become a major challenge for local and national governments as the age structures in many countries change in the direction of greater numbers of older people in society. Yet, there are many seniors in both New Zealand and Scotland who provide free labour to social services and voluntary organizations (Tuckett \& McAulay, 2005). Through volunteering many elders continue an active profile in their communities and engage in learning either at an experiential level through day to day activity or through more formalized training (Jarvis, 2001).

The theme of social inclusion in regard to older people has been grasped by both New Zealand and Scotland. It is commonplace for a myriad of services to be explicitly identified for older citizens in shopping malls, free or subsidized travel, parking arrangements, mobility scooters and wheelchair access to public facilities. In older adult education, some classes have been designated for seniors only; increasingly, as in the case of the University of the Third Age (U3A), older people have asserted their rights to plan, implement and evaluate their own educational opportunities (Boulton-Lewis, 2012). The University of the Third Age in Scotland is a self-help organisation for people no longer in full time employment or with parental responsibilities. It provides educational, creative and leisure opportunities in a friendly environment. The Scottish U3A has currently over 7,000 members in 44 U3As. Individual members are both learners and teachers, giving their services freely and they contribute to costs of using educational or cultural facilities. Among them they currently offer over 300 subjects for which there is no accreditation or validation and there are no assessments. The U3A provides a valuable route for older adults to engage in non-formal learning which is non-accredited at a comparatively low cost. It is particularly appealing to those who want flexible leisure-type programmes and which provide opportunities to meet people socially. Despite this glimpse of optimism exemplified by the U3A movement, there remains a major challenge to meet the learning needs of many older people whose mobility may be impaired or who have (perhaps inadvertently) been alienated from ordinary life chances.

\section{THE POLICY FRAMEWORK}

There are numerous policy statements made in both New Zealand and Scotland that have had some impact on the quantity and quality of educational opportunity. While it is acknowledged 
that social policy is developed in a diverse array of contexts, usually policies related to lifelong learning and ageing are of more direct relevance. In this paper, we look briefly in both countries to identify significant policies that have had an impact on educational opportunities for older adults.

New Zealand: In terms of lifelong learning in New Zealand, the previously active National Council of Adult Education (NCAE) initiated a working party in 1987 which made many recommendations, some to link active ageing and learning more explicitly (AEWP, 1987). After this time, the Tertiary Education Commission has been the official mouthpiece of Government since its establishment in 1989. It has been informed by numerous papers, including Koia! Koia! Towards a learning society (AECLWP, 2001).Throughout these documents, while reference may be made to "marginalized groups", seldom have older people been specified. In short, older adult education is not part of normal governmental consciousness; hence, little direct funding emanates from government specifically for older adult education. The major path for funding in ACE has been via literacy and numeracy but older people do not figure in this funding distribution, apart from acknowledgement within the Office of the Minister for Senior Citizens.

Policy statements regarding ageing are reasonably plentiful and usually supportive of "active ageing”, "productive ageing” or "successful ageing”. Policies have also emanated from allied services such as health and social welfare, usually asserting that individuals develop greater autonomy and resilience and become less dependent on the state (see the Department of Social Welfare, 1999). Older adults are encouraged to be more fully engaged in society in line with international policies asserting their rights to do so.

Scotland: A report published by the Scottish Government All Our Futures: Planning for a Scotland with an Ageing Population (2007a) set out a vision for Scotland which valued and benefited from the talents and experience of older people. The report identified improving health and well-being, and providing learning opportunities as key action priorities. Older adults have also become aware of the need to update their skills level for re-entry into employment.

The Scottish Government's strategy for lifelong learning, under the umbrella of Scotland's Futures Forum (2007b), agreed that policy makers have to know in what circumstances and in what forms learning would be attractive to older adults. Its key discussion document (Schuller \& Watson, 2009) also revealed that provision was not being adjusted in line with economic, social and demographic changes. In his report, Older People and Wellbeing, Allen (2008, p.5) highlighted that there is "still no 'Sure Start' for later life". Indeed, between 2004/5 and 2006/7, when adult educational funding in the UK dropped off, the number of learners in publicly-funded provision fell by over a million, with those over 65 the largest proportion of learners lost (Anderson, 2008). The international study by Kirkwood 
et al. (2008) drew attention to the undervaluing of older people and made a plea for the greatest number of older adults maintaining the best possible 'mental capital', not only to preserve their independence and wellbeing, but also to maximize their active engagement and contributions to national life.

Since 2010, Skills for Scotland: Accelerating the Recovery and Increasing Sustainable Growth has become the main lifelong learning strategy for Scotland. The strategy which has four priority themes - empowering Scotland's people, supporting Scotland's employers, simplifying the skills system, and strengthening partnerships - clarifies the government's commitment to skills and training to help address the need for skills and to improve economic performance. However, the focus has been towards young people. The potential for certain groups (such as those lacking skills in literacy and numeracy; older learners supporting sustainable growth in the economy) has not so far been fully realized.

The introduction of Individual Learning Accounts (ILAs) as a demand-focused source of funding for lifelong learning has placed the individual at the centre of learning and skills development and provides resources which can be accessed to increase control and choice over an individual's skills and learning development. In 2009-10 over 53,000 courses were attended by around 44,500 people on low incomes using ILA funding. While many older learners may have benefited, the increasing focus on work-related skills places considerable limits on the kind of programmes older people can access.

In 2014, the Scottish Government realised its new Statement of Ambition to widen access for adults to learning. The statement also focusses on the need to promote inclusion and equality with learners at the centre of the decision-making process. The Statement of Ambition seeks to make Scotland a creative and engaged learning society and recognizes the importance of adult learning in the development of the individual, the community and the country as a whole. One of the few references to older people in the statement recognises that Scotland's people are now living longer, healthier lives and that adult learning has a key role to play with this changing demographic (Statement of Ambition, 2014:1.4). While this statement is to be welcomed in that it reaffirms the rights of adults to engage in learning, it remains to be seen to what extent older adults will benefit from any new approaches.

A focus on skills and work-related programmes in Scotland has meant that adult learning opportunities are becoming increasingly market orientated and at the same time, the ability of learners to engage in learning is becoming increasingly dictated by an ability to pay for programmes. In effect, this marketization of adult learning renders older adult education as a preserve of the rich and already well-educated.

\section{HIGHER EDUCATION}

New Zealand: The system of higher education (HE) in New Zealand reflects its colonial past in that the universities have been modelled from British antecedents (Dakin, 1992). Since the mid-1980s the country has undergone significant neo-liberal reforms and directions within tertiary education have reflected this ethos. Universities, as a crucial part of the tertiary public education system, are the principal component of HE. The 20 or so Polytechnics and Institutes of Technology, typically located in medium sized cities/towns, form an important 
supplement to universities but have a stronger technical/vocational emphasis and do not necessarily offer full degrees. A special element of the tertiary education sector in New Zealand are the three whare wānanga (Māori tertiary education providers). These are Māorioriented institutions whose kaupapa (philosophy) is consistent with Māori taking greater control of their lives (self-determination).

In line with the United Kingdom (UK), tertiary education and universities in New Zealand have been pre-occupied with widening participation and the diversification of the system (Duke, 2005). Historically, universities through their centres for continuing education (in the traditional universities, originally university extension modelled from UK antecedents) have welcomed "mature students" or older students, especially in non-credit programmes. One of the benefits of continuing education for older adults in universities has been as a pathway to more formal credit studies, as a "safe place" to test the water in higher education (McGivney, 2003). Yet, as Jamieson (2007) has noted with respect to the UK, relatively few older students undertake serious degree study. This scenario is in part a reluctance of older people to enter what might be considered "alien territory" (Tett, 2004) but may also reflect less than effective marketing strategies undertaken by universities.

Scotland: The Government requires universities to prepare outcome agreements which demonstrate a commitment to widening access. Outcome agreements are between higher education institutions and the Scottish Funding Council and set out how universities will use public money to achieve public priorities. They were first required in 2012-13. While these outcome agreements encourage access from a diverse range of under-represented groups, older adults are not at the front of the queue. For example, the University of Strathclyde's agreement indicates it is committed to providing access to people from the widest possible range of backgrounds. Through its Centre for Lifelong Learning it is opening up routes into higher education, particularly within the regional community. A recent analysis of data revealed that while more than 2,000 older adults accessed education through the Centre for Lifelong Learning, only a handful of older adults aged over 50 were entering the university through other faculties.

\section{ADULT AND CONTINUING/COMMUNITY EDUCATION}

New Zealand: It is useful to interpret the role of universities in providing education for older adults in a wider context. Many, but not all, older people in New Zealand have had the opportunity to pursue their learning goals through more general adult education and/or more specific learning opportunities targeted at older learners. In the case of the former, older people have frequently participated in continuing education conducted by high schools, the Workers' Education Association (WEA), the Rural Education Activities Programme (REAPs), community houses and a host of other agencies, some of which would not identify themselves as adult education agencies. ACE in universities has traditionally been part of this open access tradition to non-credit education. In the case of the latter, there are educational programmes specifically designed by, with and for older people. These include Seniornet (a self-help agency run by older adults for older adults to become more comfortable and 
competent in the use of new information and communication technologies), the University of the Third Age and the Rauawaawa Charitable Trust (a holistic Māori organization attending to the needs of kaumatua (seniors) in Hamilton city in which the Centre for Continuing Education (CCE), the University of Waikato, played a significant supporting role).

For Pakeha (Europeans), older adult education has followed patterns of the wider ACE sector. Accordingly, those older people with substantial social capital (Field, 2003) are more adept at organising their own educational opportunities as well as taking advantage of providers who also meet their expressive and instrumental learning needs.

Under the impetus of tino rangatiratanga (self-determination), Māori education developed strongly at both tribal and national levels consistent with a lifelong learning structure. Important distinguishing features of these new forms of Māori-oriented education structures are: their involvement of Māori at local (in cities) and/or tribal sites, that is, local community participation and development; pedagogy and curricula which resonate with daily life issues; and, inter-generational engagement (Smith, 2012). Hence, older Māori (more often women) have returned to study to be better equipped to speak te reo (Māori language) with confidence to their mokopuna (grandchildren).

Scotland: As Jacobsen (1992, p.278) points out, the development of adult education was closely linked to a movement of popular enlightenment similar to that in Scandanavian countries and Germany. Cooke (2006) argues that adult education developed to fulfil a variety of functions including remedial education, improving the skills of the workforce and education for citizenship. While the classic form was evening classes, there were many other types including day schools, summer school, mutual improvement societies and selfeducation often linked to library provision (Cooke, op.cit). Following the publication of the Alexander Report (1976), four main aims of adult education were established: the reaffirmation of individuality; the effective use of resources of society; fostering a pluralist society; and education for change. Following the Alexander Report, most authorities in Scotland restructured their youth and community and adult education services into community education services. Given that learning can take place in many different situations the report became involved in the debate about formal, non-formal and informal learning contexts.

Two recent initiatives have assumed prominence in the Scottish context, The Individual Learning Accounts Scheme (ILA Scotland) mentioned earlier and the establishment of the Scottish Credit Qualifications Framework (SCQF). ILA Scotland was launched in 2004 with the intention of widening participation through providing funding for individuals and groups such as mature older learners to gain better access to education. The SCQF was created in December 2001 to launch a flexible training pathway by providing lifelong learning credits that allow for accumulations and transfer with other education and training sectors. These 
schemes have both encouraged greater participation of older adults from diverse backgrounds into both further education and higher education (Findsen \& McCullough, 2008).

The ability to access ILA funding is, as mentioned earlier, increasingly focussed on obtaining or improving qualifications for the workforce but this normally has not been the key motivation for older adults in engaging in learning.

\section{ACE IN UNIVERSITIES}

New Zealand: In earlier days in New Zealand, the system of adult education in universities was inherited from the UK as university extension (Findsen \& Harre-Hindmarsh, 1996) in the main urban centres (Auckland; Wellington; Christchurch, Dunedin). Newer universities emerged such as the University of Waikato, and set up continuing education units, mainly in the 1970s. Considerable 'rationalisation' of resources occurred within the tertiary education system, resulting in a more resource-depleted (ACE) sector. When ACE in the early 1990s entered the TEC, funding to universities became part of this scenario. Throughout the universities, liberal adult education was reduced and more vocationally-oriented and professional programmes took precedence (Findsen \& Harre-Hindmarsh, op. cit).

\section{The University of Waikato: ACE and older adult education}

The University of Waikato, which in 2014 celebrated its 50 years of existence, adopted the American model of a centre for continuing education (CCE) rather than University Extension. The CCE began in the 1970s and its expansion continued well into the 1980s when arguably it was a flagship for innovation and creativity with an established reputation in the Southern Hemisphere. The New Zealand author joined it as a continuing education officer, essentially a programme planner/curriculum developer, in the late 1970s, prior to what many adult educators see as the heyday of the field in the 1980s. The CCE offered programmes across many subject areas (e.g. in the Arts and Humanities; Human Relationships; Science) plus extensive regional outreach provision. Significantly, the CCE was connected to then emergent marginalized fields of women's studies, trade union education and Māori studies. The CCE functioned not only as a provider of adult liberal education but also as a major point of access to mature-aged students. It was an important incubator of new ideas where its relative marginality in the academy worked to its advantage (Thompson, 2000). It was a place of experimentation, especially in domains of programme develoment, in more dialogical teaching-learning methods and in academic processes.

While the mainstay of provision for the CCE was in non-credit programming, it became prominent in access/bridging type programmes for mature-aged students. Overall, however, the CCE was best known by the Hamilton city and regional areas for its programme provision in the myriad topic areas of continuing education. Amid this generalized programme, older 
adults were attracted to courses/seminars as part of the general public. On occasion, an actual course would be of more immediate relevance for older people (e.g. Preparing for Retirement; Adults Grow Too) but few programmes were planned with older adults for older adults.

\section{ACE priorities for Universities}

The generic priorities of ACE have not been the same as for the universities. The Tertiary Education Commission (TEC, 2012), as the funder of ACE to universities, expected the universities to adhere to five priorities as follows:

- Providing specialised and research informed higher-level learning that contributes directly to the creation of an advanced and rapidly evolving knowledge community.

- Contributing to the knowledge society through the preservation, dissemination and application of university research.

- Promoting the development of critical and reflective thinking, and active and informed citizenship locally, nationally and globally.

- Facilitating pathways into and through university education.

- Building capacity in the wider ACE sector.

All proposals for new courses/seminars required to be assessed against these priorities and at least one of them deemed to be appropriate. The themes of lifelong learning, outlined earlier in this paper, have some resonance with these priorities. However, the current Public-Based Research Fund (PBRF) environment of universities necessitates keen attention to research outcomes which have little direct connection with older adults' lives. Overall, in terms of the learning aspirations of older adults, these five priorities have only a loose connection. Older people are certainly part of a learning society; they have the same rights as younger citizens to be informed about societal issues; they could become mainstream credit students in the university if pathways were to be made more transparent and accessible. The 2012 announcement by government of the curtailment of funding to universities for ACE has had immediate impact in the closure of the CCE at the University of Waikato; elsewhere in the New Zealand university system, CCEs have been closed, or restructured and/or severely blunted in programme provision, usually on a strict user-pays approach. Hence, participation by older adults has been reduced commensurably.

\section{The University of Strathclyde: ACE and older adult education}

The University of Strathclyde is one of a small number of universities in the UK which has a special focus on providing for the educational needs of older adults. Through its Centre for Lifelong Learning, it offers a range of public programmes including languages, history, the arts, natural and social sciences at all levels geared towards the needs and interests of older 
adults. For more than a quarter of a century, the Centre has been involved with teaching, research and practical activities which seek to meet the needs of older adults. The programme also offers a bridge between the generations enabling young people to learn from their seniors and vice versa. The intergenerational contact has also been useful in promoting new images of both older and younger people, placing young people at the forefront of challenging ageism.

The University of Strathclyde has since 2012 been part of an international movement which is seeking to establish 'Age-Friendly' Universities (AFU)'. The initiative is preparing society for the multi-faceted challenges of Scotland's ageing demographic. The partners in the project (Dublin City University, Arizona State University and Strathclyde University), are actively encouraging older people to come into higher education institutions and to access teaching programmes across the university. The project is encouraging those who have never taken up higher education to access programmes and to encourage retired staff within universities to support the development of third age learning. The age friendly activities are targeted at promoting the quality of life of older men and women. The partnership involves teachers, researchers and learners working together in the delivery of programmes. Areas such as health and wellness, intergenerational learning, lifelong learning, distance education and cultural activities are all part of the project.

To date, the project has encouraged dialogue between personnel in the partner universities. The project is very much in its infancy, but represents a commitment at the highest level of these universities to widen participation in universities internationally by providing for the needs of older adults right across the university and to encourage research and innovation which can benefit the needs of older adults.

\section{ISSUES FOR OLDER ADULTS IN TWO UNIVERSITIES}

The following issues in each of the New Zealand and Scottish universities (the University of Waikato, and the University of Strathclyde) provide a basis for judging the extent to which older adults have been considered as active members of a university community.

\section{Funding}

Waikato: In 2011 New Zealand ACE in universities still received government funding but it was reduced by 48\% from the previous year. As a result, into 2012, the CCE became a very small operation still expected to meet a very ambitious target for the University (based on negotiated Equivalent Full-Time Students from the TEC). Despite its maintenance of a robust programme, the financial viability of the CCE became highly suspect. Within its provision, the CCE had sub-contracted arrangements with several community-based providers, 
including those for older adults. For Pakeha (Europeans), the CCE provided modest funding to a Hamilton-based 60+ group and eight regional networks. For Māori, through a formal Memorandum of Agreement (MoA), the CCE co-operated with the Rauawaawa Trust for local elders to organise and teach courses of relevance to the local iwi (tribe), Tainui.

By the TEC's removal of funding to universities, the Government threw the responsibility of ACE to the universities to fund. Given the fragile financial viability of the CCE, it is no surprise, but a disappointment, that the University itself decided to close the CCE, historically a principal disseminator of university-based knowledge to respective communities, many of which were populated with older people.

Strathclyde: The Scottish Government's aim has been to encourage greater collaboration between universities and other institutions, building on Scotland's excellent research base and harnessing the intellectual power of universities for business. As in the rest of the UK, funding is concentrated on world-leading and internationally excellent research which enhances Scotland's reputation and makes it an attractive place to do business. This objective has had a knock-on effect in the funding of lifelong learning units in universities which traditionally have been focused on providing employment related or community-based programmes for local people. Few of these units have had research as a core activity.

Employment related programmes are self-financing from student fees or in some cases, supported by grants awarded from bodies such as local authorities, hospitals or Government employment supported initiatives.

Other programmes, particularly for marginalized groups such as the unemployed, ethnic minorities and certain groups of older people are available through special Government funding or Charities (Bowl, 2014). European Union funding has been a particularly good source of funding for development projects for excluded groups, including older people, and for developing action-based research in this field.

\section{Curriculum and provision}

Waikato: The ways in which the ACE priorities are interpreted in the New Zealand University context determine what counts as knowledge (the CCE programme) and affects the potential balance of subject offerings. The CCE at the University of Waikato "punched above its weight” for its small size and limited staffing resource. Those programme areas retained until the end of 2012 included the general liberal adult education offerings (very modest in numbers); enrolment of mature age students in non-credit programmes (e.g. New Start); a community issues forum; a small component of community development; education for older adults; Māori adult education (especially through the Rauawaawa Trust) and a modicum of continuing professional education (mainly for teachers) and a little on-line education. 
Historically in universities there has been on-going tension in adult and community education between University priorities and community-based initiatives (Findsen, 2012). The effect of the TEC's University ACE priorities, even before the funding crisis, was to focus mainly on those continuing education events which had corresponding subjects taught in the University and to reduce engagement with communities outside the University, including those containing older people. Programme provision in the CCE's final years of operation became less oriented towards community development initiatives and more towards highly marketable lecture series to sustain the enrolment economy.

Strathclyde: At Strathclyde University, the Centre for Lifelong Learning has organised the largest formal education programme in Scotland directed towards older adults with some 2,000-3,000 adults participating in programmes each year. These programmes are largely short in nature and include a day, evening and weekend programme as well as a summer school focusing on the learning needs of older adults. It includes a very wide choice of subjects in, for example, languages, literature, social sciences, leisure and recreation, and the creative arts. These programmes are mainly "lower level programmes" and while rich in subject content, normally do not foster higher level critical activity or provide opportunities to debate socio-political issues. Radical education programmes are largely the concern of other voluntary agencies where greater independence can be maintained as they are not funded by Government.

In both New Zealand and Scotland, while many older adults participate in formal learning for personal development, their contribution to community development through volunteering is also a growing way in which adults engage in non-formal learning activities (Karsten \& Erlinghagen, 2009).

\section{Older persons’ participation in ACE}

Waikato: The often asked question "Who participates in university ACE programmes?” has a familiar answer in Western cultures. The proposition that white, middle-class women have dominated adult liberal education at most university sites (unless a major, usually vocational, programme attracts men) is sustained at the University of Waikato. While in general Māori and Pasifika have tended to miss out in relation to mainstream provision (Scott, 2010), the strong partnership operating between the Rauawaawa Kaumatua Charitable Trust (a capacitybuilding programme for kaumatua (elders) taught by kaumatua) in Hamilton and the CCE at the University of Waikato points to a bi-cultural commitment. Its fuller history, programming and characteristics have been recorded elsewhere (see Findsen, 2012) but these confirm a respectful, mutually-beneficial arrangement for both parties.

The CCE had co-operated with the Hamilton 60 + continuing education group (around 150200 older adults) to provide public lectures on a regular weekly cycle. A local committee of seniors constructed the programme in conjunction with an ACE advisor from the CCE. 
Similarly, the CCE offered support to eight regional towns where kindred programmes were conducted by largely autonomous 60+ groups. Hence, overall, the CCE helped senior adult education to prosper as an outreach project for many years. It could be argued that these 60+ continuing education groups have fulfilled a similar purpose to the popular independent University of the Third Age (U3A), dominated by those who have already prospered from sustained educational advantage (Boulton-Lewis, 2012). Despite the closure of the CCE at the University, these groups have continued without explicit support from the University.

Strathclyde: In Scotland, formal learning in universities is associated largely with obtaining a qualification and participation in formal education/training courses. However, the less frequent vocational pressures of later adulthood can diminish the major motivator for participation in formal education, especially where there exist other demands upon the potential learner's time. While adults generally comprise a growing proportion of formal education participants, older adults $(50+)$ are still a relatively under-represented group in mainstream credit provision.

Access programmes have been developed for adults to encourage those who lack formal entry qualifications to take an alternative qualification which acknowledges their life and work experience. Flexible entry requirements with well-developed systems of accreditation for prior learning (APL) and experiential learning have also been developed at Scotland's universities to increase participation, though this route into higher education is underdeveloped in older research intensive universities. In the main, these opportunities have been taken up by mature adults aged 23- 50 but some older adults have also participated. As older adults frequently want to re-enter the work-force, gaining recognition for employment and general life experience through APL, may assist them to obtain a work qualification through an alternative route or reduce the time needed to complete a programme.

A less usual way of engaging with students and their needs has been through the Learning in Later Life Students 'Association at the University of Strathclyde. The Association, which sees its remit to engage with people aged 50+, dates back to 1998 when its policy statement stated it sought to "establish and maintain an organisation of mature students that, as its primary concern, will commit itself to furthering the educational and social aims of the older age group in the Strathclyde Region.” The Association has some 16 clubs which have evolved from classes and which provide additional educational and social activities supplementing the work of classes through an informal learning environment. This kind of activity is highly unusual and is said to be a major factor in explaining the ongoing success of later life learning at Strathclyde for 25 years (University of Strathclyde, 2012).

\section{University-Community relationships}

Waikato: The CCE at the University of Waikato upheld a positive relationship with manifold communities throughout its operation. Collaborations immediately prior to closure included the Hamilton City Council, the Waikato Society of Arts, the Waikato District Heath Board, the Tauranga Environment Centre, the Forest and Bird Society, and Creative Tauranga. Older 
people tend to be prominent in such organizations. Some relationships were formalised with memoranda of agreement to provide much-needed financial support to community groups. In terms of pride of place in partnerships, the arrangement with the Rauawaawa Kaumatua Trust stands very tall. It is indeed ironic that the Government's cutting of funds to the University has resulted in damage to one of the high priority groups for the TEC: Mãori. In a more general sense, the CCE's closure has removed an important mode of interaction of the University with its communities.

Strathclyde: In a similar way, Strathclyde University maintains close links with local bodies such as the Glasgow City Council, Glasgow Life and other voluntary groups. These links are supported with project funding to develop programmes to encourage access for older adults. Additional funding from European Union development grants also continue to support the development of partnerships within the local scene and with European countries which support the inclusion of older adults in universities.

\section{CONCLUDING REMARKS}

A direct comparison of two universities in different cultural milieu is understandably a complex affair. While there are distinctive similarities of operation emergent from a common British colonial heritage, the geographical location in opposite sides of the world has meant that more distinctive qualities of the respective countries have percolated through to provision of older adult education. The commonality is manifested in commitment to older adults in both a wider framework of adult (liberal) education provision and more specific instances of co-operative ventures of the University (mainly through continuing education) with local older people. In both cases, there is considerable older adult learning occurring in non-formal contexts, not necessarily related to University and/or governmental objectives.

At the University of Waikato, older adult education has been one of many strands of continuing education. In the wider continuing education programme, older people have been prevalent as participants but not necessarily as co-designers. However, both the 60+ continuing education programme and the Rauawaawa Trust programme provide evidence of programmes conducted with older people to help meet their more specific learning needs. In terms of indigenous education, the Trust has received international recognition for its innovation and co-operation between a University and an iwi (Māori tribe)

(PriceWaterhouseCoopers, 2008). While not overtly intentional, the two programmes provide separate opportunities for Pakeha and Māori to exercise greater autonomy in the creation of knowledge. Despite the demise of the Centre for Continuing Education at the University, these two programmes still function primarily through voluntary contributions.

At the University of Strathclyde education of older adults continues to be one of the key strands of the continuing education programme. Its city centre location in Glasgow and its 
ability to draw from a population of approximately 2.5 million in the local area enables it to focus on the needs of a particular group, older adults, whose needs have for a long time been neglected.

There is little room for smugness in observing what has happened in these two universities' engagement with lifelong learning. Supportive policies and funding are two major areas of omission. In the case of the University of Waikato, the demise of continuing education was somewhat predictable, given the New Zealand Government's historical ambivalence to funding Adult and Community Education. Even more problematic is the notion that older adult education should receive public money. When observing credit education programmes to which older people have ready access, there is little evidence of support at either a national or a more localised university level. At Strathclyde, despite its strong non-credit offerings, the trickle-on effect to "real education" in terms of degree studies is negligible. In terms of an enrolment economy, older adult education has minimal sway unless it is connected to universities' pre-occupations of recruitment, retention, progression and outcomes (Duke, 2005). However, if numbers of traditional students (those fresh from high school) dwindle, there may well be a surge of interest from universities in recruitment of older adults motivated by a financial imperative.

A seemingly neglected domain of adult learning for both providers in these case studies is that of learning for work or employability. Strathclyde University, through its various projects, has made some inroads into this area of older adult activity. Just as wider society has not considered older people as being a significant force in the labour market, universities have taken too little cognisance of instrumental education for older adults whether for a new "encore" career or for them to retain current employment against the threat of younger people displacing them (see Findsen \& McCullough, 2008). The fixation on liberal adult education in universities has tended to blind these same institutions to other useful knowledge-creation pathways for older adults.

Another issue facing both these institutions within institutions is the concentration in both countries' universities on research intensity. In the case of the New Zealand University, the Public-Based Research Fund assumes major financial importance for the continuance of individual academics as well as the University as a whole. In the Scottish context, the same mentality applies. Hence, lifelong learning centres have tended to focus on practice and professional development oriented to improve institutional performance in provision rather than embedding research into the centres themselves. Hence, the peripheral location of lifelong learning, exemplified in a paucity of high quality research, has led to a diminution of commitment to these centres.

The character of adult learning in society more generally is forever changing. The majority of older adults learn via informal learning experiences or through non-formal education (Findsen, 2005). The advent of ICT developments, especially the internet, has rendered 
formal education less relevant unless the modes of operation better reflect the realities of older people's lives. Hence, blended learning is assuming greater significance for universities (including for older adults). In addition, inter-generational learning programmes are gaining momentum across the globe (see Schmidt-Hertha, Kraseovec \& Formosa, 2014, for more explanation on these trends in Europe).

Another issue which both these universities' lifelong learning centres have inadequately addressed is that of fourth age learning (Laslett, 1989). While it is more difficult for more dependent older learners to come into the university, it is possible for the university to go to the learners. This is also a relatively neglected area within educational gerontology and is one of considerable scope providing higher education institutions have a will to do so. Such an imperative is more likely to eventuate if government policy links financial reward to such outreach.

Overall, while the two universities' programmes on older adult education have illustrated an historic commitment to serve the needs of older people the considerable threat of increasingly neo-liberal ideologies has played out slightly differently in the two countries' contexts. The challenge for the future will be to ensure that the needs of this ever expanding group of adults are not overlooked in universities. 


\section{REFERENCES}

Allen, J. (2008) Older People and Wellbeing. London: Institute of Public Policy Research (IPPR).

Anderson, S. (2008). Later life learning: A review of the literature. Milton Keynes: the Association for Education and Ageing (UK).

(AECLWP) Adult Education and Community Learning Working Party (2001).

Koia! Koia! Towards a learning society: the role of adult and community education.

The report of the adult education and community learning working party.

Wellington: Ministry of Education.

(AEWP) Ageing and Education Working Party (1987). Ageing and lifelong learning in New Zealand. Wellington: National Council of Adult Education.

Beatty. P.T. \& Visser, R.M.S. (2005) (Eds.). Thriving on an aging workforce: Strategies for organizational and systemic change. Malabar, Florida: Krieger Publishing Co.

Boulton-Lewis, G. (2012). Issues in learning and education for the ageing. In G. BoultonLewis \& M.Tam (Eds). Active ageing, active learning, Springer: Dordrecht, pp.21-33.

Bowl, M. (2014). Adult education in changing times. Leicester: NIACE.

Cooke, A. (2006) From Popular Enlightenment to Lifelong Learning: A History of Adult Education in Scotland 1707-2005, Leicester: NIACE

Dakin, J. (1992). Derivative and innovative forms of adult education in Aotearoa New Zealand, New Zealand Journal of Adult Learning, 20 (2), 29-49.

Davey, J. A. (2006). The labour market. In Boston, J. \& Davey, J.A. (Eds.) Implications of population ageing: Opportunities and risks. Victoria University of Wellington: Institute of Policy Studies, pp. 189-220.

Davey, J. \& Cornwall, J. (2003) Maximising the potential of older workers. Wellington: New Zealand Institute for Research on Ageing, Victoria University of Wellington.

Department of Social Welfare (1999). From welfare to well-being and strengthening families. Wellington: Ministry of Social Policy. 
Duke, C. (2005). (Ed.) The tertiary moment: What road to inclusive higher education? Leicester: NIACE.

Field, J. (2003). Social capital, London: Routledge.

Findsen, B. (2012). University and community engagement through continuing education: The case of the University of Waikato and the Rauawaawa Trust, in Jones, P., Storan, J. Hudson, A. \& Braham, J. (Eds) Lifelong learning and community development (pp. 43-55). University of East London: Forum for Access and Continuing Education.

Findsen, B. (2005). Learning later. Malabar, Florida: Krieger Publishing Co.

Findsen, B. \& Formosa, M. (2011). Lifelong learning in later life: A handbook on older adult learning. Rotterdam: Sense Publishers.

Findsen, B. \& McCullough, S. (2008). Older adults' engagement with further and higher education in the West of Scotland: Tracking educational journeys (Final Report). Glasgow: The West of Scotland Wider Access Forum and the Department of Adult and Continuing Education, University of Glasgow.

Findsen, B. \& Harré-Hindmarsh, J. (1996). Adult and Community Education in the Universities. In J. Benseman, B. Findsen, \& M. Scott (Eds), The Fourth Sector: Adult and Community Education in Aotearoa/New Zealand (pp. 193-209). Palmerston North, New Zealand: The Dunmore Press.

Jamieson, A. (2007). Higher education study in later life: what is the point? Ageing \& Society, 27, 363-384.

Jarvis, P. (2001). Learning in later life. London: Kogan Page.

Jacobsen, B. (1992) 'Denmark' in P. Jarvis (Ed.), Perspectives on Adult Education and Training in Europe. Leicester: NIACE

Jesson, J. (2010). Adult and community education. In Thrupp, M. \& Irwin, R. (Eds). Another decade of New Zealand education policy: Where to now? Hamilton: The Wilf Malcolm Institute of Educational Research, pp. 131-147. 
Karsten, H. \& Erlinghagen, M. (2009). Dynamics of volunteering in older Europeans, The Gerontologist, 50 (2), 170-178.

Kirkwood, T., Bond, J., May, C., McKeith, I. and Teh, M. (2008) Foresight mental capital and wellbeing project: making the most of ourselves in the 21st century. London: The Government Office for Science.

Laslett, P. (1989). A fresh map of life: The emergence of the Third Age. London: Weidenfeld and Nicholson.

Lindberg, D. \& Marshallsay, Z. (2007). Older workers’ perspectives on training and retention of older workers. Adelaide, South Australia: National Centre for Vocational Education Research \& the Australian Government.

Mark, R. (2013). From Adult Learning to Lifelong Learning in Scotland, Chapter 84, in Bryce, T., Humes, W. Gillies, D., \& Kennedy, A. Scottish Education (4 ${ }^{\text {th }}$ Edition). Edinburgh University Press, pp774-783.

McGivney, V. (2006). Adult learning at a glance. Leicester: NIACE.

McGivney, V. (2003). Adult learning pathways: through routes or cul-de-sacs?. Leicester: NIACE.

Phillipson, C. (1998). Reconstructing old age: New agendas in social theory and practice. London: Sage Publications Inc.

Phillipson, C. (2000). 'Critical educational gerontology: Relationships and future developments'. Chapter 3 in Glendenning, F. (Ed) Teaching and learning in later life: Theoretical implications (pp.25-37). Aldershot: Ashgate Publishers.

PriceWaterhouseCoopers (2008). Adult and community education: Economic evaluation of adult and community education outcomes. August, PWC.

Rothwell, W.J., Sterns, H.L., Spokus, D. \& Reaser, J.M. (2008). Working longer: New strategies for managing, training, and retaining older employees. New York: American Management Association. 
Schmidt-Hertha, B., Kravosec, S.J. \& Formosa, M. (2014). (Eds). Learning across generations in Europe. Rotterdam: Sense Publishers.

Scott, D. (2010). Non-formal and formal learning - adults in education. Wellington: Ministry of Education.

Scottish Government (2004) Working and learning together to build stronger communities Scottish Executive Guidance for Community Learning and Development. Available at: http://www.gov.scot/Publications/2004/02/18793/32157

Scottish Government (2007a) All Our Futures: Planning for A Scotland with an Ageing Population (2007). Edinburgh: Scottish Government. Available:http://www.scotland.gov.uk/Topics/People/Equality/18501/Experience.

Scottish Government (2007b) Scotland's Futures Forum: Growing older and wiser together: A future's view on positive ageing. Edinburgh: Scottish Government. Available at:http://www.scotlandfutureforum.org/assets/library/files/application/1215680454.pdf

Scottish Government (2010) Skills for Scotland: Accelerating the Recovery and Increasing Sustainable Growth (2010)

Available at: http://www.gov.scot/Topics/Education/skills-strategy

Scottish Government (2014) Statement of Ambition for Adult Learning

Available at: $\underline{\text { http://news.scotland.gov.uk/News/Learning-for-all-b15.aspx }}$

Schuller, T. \& Watson, D. (2009) Learning Through Life: Inquiry into the Future for Lifelong Learning, Leicester: NIACE

Scottish Education Department (1975) Adult Education: The Challenge of Change. The Alexander Report, Edinburgh: HMSO

Statistics New Zealand (2013). 2013 Census Quickstats about national highlights. (www. stats.govt.nz). Wellington: New Zealand Government.

Smith, L.T. (2012). Decolonizing methodologies: research and indigenous peoples. London: Zed Books. 
(TEC). Tertiary Education Commission (2012). Priorities for TEIs, at

http://www.tec.govt.nz/Funding/Fund-finder/ACE-in-communities/ACE-in-TEIs (accessed 31 May 2012)

TEC (Tertiary Education Commission) (2010). Tertiary Education report: Introduction to the key issues in Tertiary Education. Available through http://www.tec.govt.nz

Tett, L. (2004). Mature working class students in an 'elite' University: Discourse of risk, choice and exclusion. Studies in the Education of Adults, 36 (2), 252-264.

Thompson, J. (2000) (Ed). Stretching the Academy: The Politics and Practice of Widening Participation in Higher Education. Leicester, NIACE.

Thorpe, T. (2011) Health Numbers: a Statistical View of Health of Oder People in Scotland British Geriatrics Society http://www.bgs-scotland.org.uk/index.php/about$\underline{13 / \text { ageinghealthstats }}$

Tuckett, A. \& McAulay, A. (2005). (Eds.) Demography and older learners. Leicester: NIACE.

University of Strathclyde and the Scottish Funding Council Outcome Agreement (2014-5).

Available:http://www.strath.ac.uk/media/publications/pressreleases/2012/Outco me Agreement 2012-13 FINAL Version.pdf

University of Strathclyde. (2012). 25 Years of Learning at Strathclyde. Centre for Lifelong Learning, Glasgow. 